\title{
PsZICHODERMATOLÓGIA ÉS EGÉSZSÉGPSZICHOLÓGIAI ELLÁTÁS A BŐRGYÓGYÁSZATBAN
}

\section{A BŐR ÉS A LÉLEK KAPCSOLATA}

A pszichodermatológia olyan tudományterület, mely a lélek, az idegrendszer és a bőr közötti kölcsönhatásokat vizsgálja, négy fö szakma bevonásával: pszichiátria, pszichológia, neurológia és bőrgyógyászat (França et al., 2017). Már Hippokratész (Kr. e. 460377 ) is megemlítette írásaiban a stressz hatásait, olyan emberekre hivatkozva, akik érzelmi megterhelés hatására kitépték a hajukat (França et al., 2013). A trichotillomania kifejezés 1889-ben jelent meg először, amikor egy francia bőrgyógyász, Hallopeau Francois Henri jellemezte egy nőpáciens esetét, aki kitépte a haját. Az angol sebész és bőrgyógyász, William James Erasmus Wilson 1857-ben írta meg $A$ bör betegségei címü könyvét, melyben használta a bőrneurózis kifejezést, a következő kórképekre értve azt: téveszmés parazitózis, foltos hajhullás (alopecia areata), bőrviszketés (pruritus), hipopigmentált léziók (melyek oka a melanocyták számának vagy melanintermelésének csökkenése vagy hiánya, például vitiligo esetén (Kárpáti et al., 2019). A téveszmés parazitózis (mely egy fóbiás állapotot jelent, amely intenzív viszketéshez és bőrkaparáshoz vezet, a betegek hamisan gondolják, hogy bőrparazitáik vannak) elnevezést az angol bőrgyógyász, Robert Willan 1799-ben és Johann Heinrich Jordens 1801-ben adták az említett bőrbetegségnek (França et al., 2013).

A modern pszichodermatológia a biopszichoszociális betegségmodellre támaszkodik (Gieler et al., 2020). Sok kutató szerint a biopszichoszociális modellt ki kell terjeszteni a spirituális dimenzióra is, mivel a vallásnak és a spiritualitásnak is kiemelt jelentősége van a magas színvonalú orvosi képzés és a klinikai gyakorlat szempontjából, és ez indokolhatja a biopszichoszociális-spirituális modell kifejezés használatát (Saad et al., 2017). A bőr láthatósága a dermatológiát különleges helyzetbe hozza a különböző klinikai területek között, és ez különösen fontossá teheti a komplex pszichoszomatikus megközelítés alkalmazását a pácienseknél (Gieler et al., 2020).

Egészségügyi szakemberek körében a pszichodermatológia tanulmányozása új lendületet kapott az elmúlt két évtizedben (Jafferany \& Franca, 2016). Tanulmányukban Jafferany és Franca (2016) a terület következő négy fontos szervezetét említik meg: Association for Psychoneurocutaneous Medicine of North America (APMNA), European Society of Dermatology and Psychiatry (ESDaP), Psychodermatology UK, Japanese 
Society of Psychosomatic Dermatology. Hazánkban a bőr és a lélek kapcsolódásaival foglalkozó társaság a Magyar Dermatológiai Társulat (MDT) Pszichodermatológiai Szekciója.

\section{PszichodermatológiaI BetegségeK tíPuSAI}

Négy típusba sorolhatjuk a pszichodermatológiai betegségeket: pszichofiziológiai bőrbetegségek; pszichiátriai betegségek bőrtünetekkel; bőrbetegségek pszichiátriai tünetekkel; egyéb zavarok (Jafferany, 2007; Jafferany, Ferreira et al., 2020; Jafferany \& Franca, 2016; Koo \& Lee, 2003). Ezen kategóriák meghatározásait és példákat olvashatunk a különböző típusokra az 1. táblázatban.

\begin{tabular}{|l|l|l|}
\hline $\begin{array}{l}\text { Pszichodermatológiai } \\
\text { betegségkategória }\end{array}$ & \multicolumn{1}{|c|}{ A betegségtípus leirása } & \multicolumn{1}{|c|}{ Példák } \\
\hline $\begin{array}{l}\text { Pszichofiziológiai } \\
\text { bőrbetegségek }\end{array}$ & $\begin{array}{l}\text { Ezeket a bőrbetegségeket pszichés stressz } \\
\text { válthatja ki vagy súlyosbíthatja. }\end{array}$ & $\begin{array}{l}\text { atópiás dermatitisz } \\
\text { pikkelysömör } \\
\text { akne } \\
\text { foltos hajhullás } \\
\text { (alopecia areata) } \\
\text { rosacea } \\
\text { seborrheás dermatitisz } \\
\text { krónikus spontán } \\
\text { urticaria }\end{array}$ \\
\hline $\begin{array}{l}\text { Pszichiátriai } \\
\text { betegségek } \\
\text { bőrtünetekkel }\end{array}$ & $\begin{array}{l}\text { Ezek a zavarok a „sztereotip” pszichoder- } \\
\text { matológiai betegségek, melyeknél a hát- } \\
\text { térben pszichopatológia húzódik meg, } \\
\text { vagy lelki konfliktusok. }\end{array}$ & $\begin{array}{l}\text { testdiszmorfiás zavar } \\
\text { trichotillomania } \\
\text { téveszmés parazitózis } \\
\text { dermatitis artefacta } \\
\text { bőrkapirgálás zavar }\end{array}$ \\
\hline $\begin{array}{l}\text { Bőrbetegségek } \\
\text { pszichiátriai } \\
\text { tünetekkel }\end{array}$ & $\begin{array}{l}\text { Hangsúlyos érzelmi problémák léphet- } \\
\text { nek fel a bőrbetegség következtében, és a } \\
\text { pszichológiai következmények súlyosab- } \\
\text { bá válhatnak a fizikai tüneteknél. }\end{array}$ & $\begin{array}{l}\text { vitiligo } \\
\text { hemangióma } \\
\text { halbőrbetegség } \\
\text { (ichthyosis) } \\
\text { rhinophyma }\end{array}$ \\
\hline Egyéb zavarok & $\begin{array}{l}\text { Ebbe a csoportba egyéb diagnózisok tar- } \\
\text { toznak, illetve pszichiátriai és bőrgyó- } \\
\text { gyászati gyógyszeres kezeléssel összefüggón } \\
\text { mellékhatások is. }\end{array}$ & $\begin{array}{l}\text { égó száj szindróma } \\
\text { (glossodynia) } \\
\text { Gardner-Diamond } \\
\text { szindróma }\end{array}$ \\
\hline
\end{tabular}

1. táblázat: Pszichodermatológiai betegségek típusai (Jafferany, 2007; Jafferany, Ferreira et al., 2020; Jafferany \& Franca, 2016; Koo \& Lee, 2003 nyomán). 
A dermatitis artefacta diagnózis önkezüleg ejtett bőrsérülésekre utal, a rhinophyma az orr duzzanatára utal kollagénszerü kötőszövet-felszaporodás következtében, a GardnerDiamond szindróma ritka kórkép, mely a bőrön vagy bőr alatt jelentkező csomók okozta lila foltokkal jár föleg karokon, lábakon, melyek rendszerint heg nélkül, hiperpigmentációval gyógyulnak (Kárpáti et al., 2019).

Ferreira és Jafferany (2021) publikálták a pszichobőrgyógyászati kórképek egy új osztályozási rendszerét. Az újítások mellett modelljük elemei több ponton hasonlítanak jelen könyvfejezetben bemutatott klasszifikációs rendszerre, mely megjelenése óta széles körben ismertté vált szakemberek körében.

\section{BőRBETEGSÉGEK ÉS A STRESSZ}

Az előzőekben láthattuk, hogy a pszichofiziológiai bőrbetegségeknek kiváltó tényezője lehet a stressz és súlyosbíthatja is az említett diagnózisokat. Emellett a stressz mértéke kapcsolódhat az életminőség szintjéhez is bőrbetegségeknél (Dixon et al., 2018). Milyen módon jön létre ez a kölcsönhatás?A pszichés stressz közvetlen hatással lehet a bőr barrier/védő funkciójára (Orion \& Wolf, 2012) és az immunparaméterek széles skálájára, amelyek közvetlenül befolyásolhatják a bőr állapotát (Gupta \& Gupta, 2013). Fontos megjegyeznünk, hogy háromféle stressztényező is hathat bizonyos bőrbetegségek alakulására:

a) A bőrbetegséggel kapcsolatos stressz, például annak következtében, hogy láthatóak a tünetek (Gupta \& Gupta, 2013). Ezt a kategóriát kiegészíthetjük a „mindennapi nehézségekkel”. Ilyen stresszforrás érvényesülhet például akkor, ha pikkelysömörös tünetek súlyosbodnak megnőtt felelősséggel járó feladatok vállalása, elvárásoknak való nehéz megfelelés, vizsgahelyzetek idején (Nguyen et al., 2014).

b) Jelentős stresszteli életesemények, például a munkahely elvesztése, vagy házastársi konfliktusok (Gupta \& Gupta, 2013).

c) Traumatikus életesemények, például múltbéli súlyos elhanyagolás, szexuális bántalmazás (Gupta \& Gupta, 2013).

A pszichodermatológiai betegek ellátása szempontjából fontos lehet, hogy a bőrgyógyász, a pszichológus, a pszichiáter és a háziorvos jártas legyen a stresszhatásokból adódó „klinikai kifejeződések” felismerésében a bőrön (Rodriguez-Vallecillo \& WoodburyFariña, 2014).

\section{PsZichológiaI téNYezőK BőRBETEgSÉGeKNÉL}

Sokféle pszichológiai, pszichopatológiai tényező hathat a bőrbetegek életminőségének szintjére. A következőkben összegyüjtöttem néhányat ezen faktorok közül:

a) Stigmatizáció. A megbélyegzést vagy stigmatizációt leírhatjuk úgy, hogy megbámulják a pácienst vagy zavartan viselkednek a környezetében, a barátságos viselkedés 
hiányát vagy ellenséges viselkedést tapasztalja (Lawrence et al., 2006). Bőrbetegek gyakran tapasztalhatnak megbélyegzést, amit Halioua és munkatársai (2016) pikkelysömörös pácienseknél olyan tévhitekkel magyaráz, miszerint fertőzőek a tüneteik vagy amiatt, mert alacsony a higiéniai szintjük. A kutatásokban jellemzően önbeszámolós eszközzel az észlelt stigmatizációs élményeket szokták vizsgálni a témakörben. Acne vulgaris-szal (közönséges aknéval) diagnosztizált pácienseknél Kotekoglu és munkatársai (2020) azt találták, hogy az észlelt megbélyegzés magas szintje alacsonyabb életminőségértékekkel, magasabb (bőrgyógyász által leírt) betegség-súlyossággal és depressziós mértékkel függtek össze. Ezek alapján azt állapították meg, hogy a magas mértékű stigmatizáció károsan hathat a páciensek énhatékonyság és önbecsülés érzésére, ami rossz hatással lehet a kezeléssel való együttműködésükre. Az ilyen páciensek számára a megbélyegzéssel kapcsolatos edukációt és pszichoterápiát javasoltak (Kotekoglu et al., 2020). Pikkelysömörrel diagnosztizáltaknál is találtak pozitív összefüggést az orvosaik által megállapított betegség-súlyosság mértéke és a páciensek vélt megbélyegzettség szintje között (Kowalewska et al., 2021). Hawro és munkatársai (2017) eredményei szerint azoknál a pácienseknél volt magasabb az észlelt stigmatizáció mértéke, akiknek a kéz hátsó részén voltak pikkelysömörös tüneteik, azokhoz képest, akiknek tüneteik körmeiken, tenyerükön, arcukon vagy a nemi szervek területén jelentkeztek. Olyan pácienseknél is magasabb volt a vélt megbélyegzés mértéke, akik nem tudták eltakarni tüneteiket (Hawro et al., 2017).

Az észlelt stigmatizáció alkotóelemei hasonlítanak a bőrrel kapcsolatos szégyenérzet bizonyos elemeihez. Ennek mérésére alkalmas eszköz a Bör Szégyen Skála (SSS-24) (Homayoon et al., 2020), mely olyan állításokat tartalmaz, mint például „kerülöm, hogy a tükörben nézzem a bőrömet”, „mások bámulják a bőrömet”, „gyönyörű a bőröm”, „szégyellem a bőrömet” vagy „aggódom, hogy mások szerint hogy néz ki a bőröm” (Scott, 2004). Hiebler-Ragger és munkatársai (2020) vizsgálatában bőrbetegek jelentősen magasabb bőr szégyenérzet szintről számoltak be, mint a kontrollszemélyek, és mindkét mintánál pozitív együttjárást mutatott a bőr szégyenérzet mértéke a pszichés distressz szintjével. Az ESDaP (European Society of Dermatology and Psychiatry) társasága második európai pszichodermatológiai vizsgálatában 16 országban megszervezett felmérések - melyben Magyarországról szegedi adatfelvételek értékei is szerepelnek eredményeinek publikálását tervezi a stigmatizáció témaköréből (a 2. ESDaP pszichodermatológiai projektről lásd: Dalgard et al., 2018; az 1. ESDaP pszichodermatológiai projektről lásd ennek a könyvfejezetnek a 4.b. pontját).

b) Kötődés. A kötődés fogalma egy érzelmi kapcsolódásra utal, amely a csecsemő és elsődleges gondozói közötti korai interakciók keretében alakul ki (Bowlby, 1977). A gondozók felé irányuló kötődés hatással van a későbbi, az illetőhöz közel álló személyekkel kapcsolatos interperszonális elvárásokra, érzelmekre és viselkedésekre (Hazan \& Shaver, 1987). A kötődés két szempontból is hasznos lehet, ha témájává válik a bőrbetegeknek nyújtott egészségpszichológiai támogatásnak: bőrgyógyászati betegek spe- 
ciális kötődési jellemzői miatt; és mert bizonyos bőrbetegségeknél a kötődés kapcsolódhat a bőrgyógyászati életminőség szintjéhez.

Az ESDaP (European Society of Dermatology and Psychiatry) társasága megszervezett egy többközpontú tudományos kutatást 13 európai ország részvételével (Dalgard et al., 2015), Magyarországon az SZTE ÁOK Bőrgyógyászati és Allergológiai Klinikán történtek vizsgálatok (Szabó et al., 2017). A vizsgálat célja a bőrbetegségek pszichológiai terhének felmérése volt, és bőrbetegek kötődési stílusai is feltérképezésre kerültek. A felmérés során a kutatócsoportok 4994 résztvevőt, 3635 felnőtt bőrgyógyászati járóbeteget és 1359 egészséges résztvevőt vizsgáltak meg. Az eredmények szerint a krónikus bőrbetegek kisebb mértékben voltak képesek függeni másoktól, kényelmetlenebbnek érezték a másokkal való közelséget és intimitást, de hasonló mértékủ szorongást éltek át kapcsolataikban, mint a kontroll-személyek. Hasonló arányban fordultak elő biztonságosan $(68,7 \%$ vs. $69,8 \%)$ és bizonytalanul kötődő (31,3\% vs. 30,2\%) résztvevők a két csoportban (Szabó et al., 2017).

A kötődés négy stílusát (biztonságos és a bizonytalan ködődés három típusa: aggodalmaskodó, elkerülő, bizalmatlan) különböztette meg Bartholomew és Horowitz (1991). Modelljükben a kötődési stílusok két dimenzió mentén jellemezhetőek: az önmagunkról és a másokról kialakított kép mentén, mindkettő lehet pozitív és negatív is, miszerint önmagunkat szeretetreméltónak, illetve másokat szerethetőnek vélünk-e (Bartholomew \& Horowitz, 1991). Elméletük szerint a biztonságos kötődés arra utal, hogy valaki szerethetőnek tartja magát és másokat elfogadónak gondol, amíg a három bizonytalan kötődési stílus esetén az illető ebben a két tekintetben vagy magát, vagy másokat negatívan értékeli (Bäckström \& Holmes, 2001). Különböző tanulmányokban vizsgálták bizonyos bőrbetegségeknél a bőrgyógyászati életminőség szintje és a kötődési jellemzők közötti kapcsolatokat. Az életminőség alacsony szintjével kapcsolódtak össze egyes bizonytalan kötődési stílusok jegyei pikkelysömörös (Esposito et al., 2020), krónikus csalánkiütéses (Barbosa et al., 2011) és atópiás dermatitiszes (Dieris-Hirche et al., 2012) pácienseknél.

c) Megküzdés a börbetegséggel. A stresszel való megküzdési stratégiák mellett a bőrbetegség tüneteivel való megbirkózási módszerek is hatással lehetnek a páciensek életminőségére. Miniszewska (2007) három bőrbetegséggel kapcsolatos megküzdési stratégiát írt le egy skála kapcsán (melyekből a másodikat tartotta adaptívnak): tehetetlenség/reménytelenség, „harci szellem”, figyelemelterelés/katasztrofizálás. Ograczyk és munkatársai (2014) szerint pikkelysömörös pácienseknél a tehetetlenség/reménytelenség és a figyelemelterelés/katasztrofizálás alskálák magas pontszámai alacsony életminőség-értékekkel jártak együtt; a „harci szellem” alskála magas pontszámai negatív kapcsolatot mutattak a szociális szférát érintő életminőség-károsodással, tehát akik ezt a stratégiát alkalmazták, kevesebb problémával találkozhattak társas helyzetekben. Emellett a magas „harci szellem” alskála értékekkel rendelkezők kevésbé súlyos viszketésről és kevesebb viszketéses epizódról számoltak be. 
d) Alvásminöség. A bőrbetegségek megnehezíthetik a jó alvásminőséget és napközben aluszékonyságot is okozhatnak. Hawro és munkatársai (2020) 104 pikkelysömörös pácienst vizsgáltak, a megkérdezettek 39\%-a számolt be alvásproblémákról, leggyakrabban éjszakai ébredésekről (33\%-uk) és napközbeni álmosságról (30\%-uk). Azok a páciensek, akik beszámoltak viszketésről, jelentősen többször számoltak be elalvási nehézségről, mint akik nem jeleztek viszketést (Hawro et al., 2020). Adamo és munkatársai (2015) összehasonlították 50 orális lichen planus-os (a nyálkahártya lichen tünet a buccalis nyálkahártyán, és gyakran a nyelven és az ajkakon is megfigyelhető foltos, hálózatos vagy elágazódó fehéres rajzolattal jár, vagy diffúz fehéres elszíneződéssel /Kárpáti et al., 2019/) páciens alvásminőségét 50 egészséges kontrollszemélyével, és azt találták, hogy a bőrbetegek alvásminősége alacsonyabb szintű volt a kontrollcsoportéhoz képest. Elkülönítették a pácienseket jó alvók (29 fö) és rossz alvók (21fö) csoportjára, és az utóbbi csoportnak jelentősen magasabbak voltak a szorongásos és a depressziós értékeik: a rosszul alvó bőrbetegek 86\%-ánál enyhe depressziót és mindegyiküknél enyhe szorongást tapasztaltak.

e) Koherencia-érzés. Ograczyk és munkatársai (2017) 46 krónikus urticaria-s (csalánkiütéses) páciens és 33 egészséges kontrollszemély vizsgálatával azt találták, hogy a koherencia-érzés globális értéke és három faktorának pontszámai is negatív összefüggésben álltak a szorongásos és a depressziós szinttel (a pácienseknél és a kontroll-csoportnál is), illetve a globális koherencia-érzés érték negatív együttjárást mutatott a betegség súlyosságával. A szerzők szerint a koherencia-érzés egy védőtényezőnek mutatkozott a szorongás és a depresszió ellen, emiatt érdemes krónikus csalánkiütéses páciensek terápiás tervében olyan pszichológiai beavatkozásokat alkalmazni, amelyek a személyes erőforrásokat fejlesztik (Ograczyk et al., 2017).

f) Érzelmek. A PANAS skálán 10 pozitív jellegű és 10 negatív jellegü érzelemmel kapcsolatosan kell bejelölni, hogy a kitöltő átlagosan milyen gyakran érzi az adott érzelmeket, és a mérőeszköz kiértékelése megmutatja, hogy az illetőre milyen mértékben jellemző a pozitív érzelmi, illetve a negatív érzelmi beállítódás (Watson et al., 1988). Martín-Brufau és munkatársai (2015) 823 pikkelysömörös páciens megkérdezésével állapították meg, hogy a vizsgált bőrbetegeknél a tünetek kiterjedtsége és súlyossága pozitív együttjárást mutatott a negatív és a szubmisszív jellegü érzelmek gyakoriságával, negatív összefüggésben állt a dominanciához kapcsolódó érzelmekkel és nem állt összefüggésben a pozitív érzelmekkel. Eredményeik alapján azt feltételezték, hogy a pikkelysömörös bőrlléziók kiterjedtsége és súlyossága és az érzelmek típusai között kapcsolat állhat fenn (Martín-Brufauetal et al., 2015).

g) Pszichopatológiai faktorok. Számos tanulmányt, kutatást publikáltak a közelmúltban arról, hogy milyen pszichopatológiai jegyek, pszichiátriai tünetek jellemzőek bőrbetegeknél.

Az ESDaP társasága a már említett, első európai pszichodermatológiai vizsgálatában (Dalgard et al., 2015) a résztvevő páciensek 17,2\%-a mutatott klinikailag jelentős szo- 
rongást (legnagyobb arányban pikkelysömörrel és lábszárfekéllyel diagnosztizáltak), 10,1\%-uk klinikailag jelentős depressziós tüneteket (legnagyobb arányban lábszárfekéllyel, kéz ekcémával és atópiás dermatitisszel diagnosztizáltak), szuicid ideációról 12,7\%-uk számolt be (leggyakrabban pikkelysömörrel kezeltek) és mindhárom tényező szintje magasabb volt, mint a kontroll-személyeké (Dalgard et al., 2015).

Mavrogiorgou és munkatársai (2020) 212 olyan pszichiátriai kezelést kapott páciens jellemzőit vizsgálták meg, akiknek bőrgyógyászati betegsége is volt. A pszichiátriai betegek 35,4\%-a pikkelysömörrel, 22,6\%-a atópiás dermatitisszel is diagnosztizálva volt. A páciensek leggyakoribb pszichiátriai diagnózisai a következők voltak: 45,3\%-uknál hangulatzavarok (BNO-10 szerint F30-F39 kódokkal, legnagyobb részüknél depreszszió), 19,3\%-uknál szorongásos, kényszeres, traumával és stresszorral összefüggő, diszszociatív zavarok és szomatikus tünet zavarok (BNO-10 szerint F40-F48 kódokkal, legnagyobb részüknél traumával és stresszorral összefüggő zavar), 13,7\%-uknál szerrel kapcsolatos és addiktív zavar (BNO-10 szerint F10-F19 kódokkal, legtöbbjüknél alkohollal kapcsolatos zavar), 11,8\%-uknál szkizofrénia spektrum és más pszichotikus zavarok (BNO-10 szerint F20-F29 kódokkal), 11,8\%-uknál organikus és szimptomatikus mentális zavarok (BNO-10 szerint F00-F09 kódokkal) és 2,8\%-uknál a felnőtt személyiség és viselkedés zavarai (BNO-10 szerint F60-F69 kódokkal) (Mavrogiorgou et al., 2020).

Jafferany, Afrin és munkatársaik (2020) megemlítik, hogy a saját bőrüket károsító páciensek esetén fontos a borderline személyiségzavar fennállását felvetni a bőrgyógyászatban, illetve hogy kozmetológiai beavatkozásokra érkező pácienseknél érdemes a nárcisztikus személyiségzavar jegyeit figyelni, hogy fennállnak-e az adott személyeknél.

Az eddigi kiemelések alapján úgy tủnik, hogy a szorongás és a depresszió szintjének szủrése meghatározó feladat lehet a bőrgyógyászatban. Egészséges személyekhez viszonyítva magasabb szorongásos és depressziós értékeket találtak pikkelysömörös pácienseknél több tanulmányban is (Karia et al., 2015; Kurd et al., 2010; Matiushenko et al., 2020), és alopecia areata-soknál (foltos hajhullással érintetteknél) is hasonló jelenséget észleltek (Karia et al., 2015).

Fontos megemlítenünk a bőrgyógyászati pszichopatológiai faktorok közül a testdiszmorfiás aggodalmakat (Danesh et al., 2015). A kozmetológiai beavatkozásokra érkező pácienseknél különösen fontos a testdiszmorfiás zavar észlelése, de más bőrtüneteknél is fontos lehet a betegség felismerése. Marron és munkatársai (2020) acne vulgaris-szal (közönséges aknéval) kezelteknél állapították meg, hogy 10,6\%-uknál volt kimutatható testdiszmorfiás zavar. Akiknél kimutatható volt, ők átlagosan legalábbi napi két óráig aggódtak megjelenésük miatt, kényszeres viselkedésformáik közül 90,7\%-uk gyakran ellenőrizte külsejét tükrökben, 79,1\%-uk eltakarta tüneteit, 72,1\%-uk sminket használt rendszeresen (Marron et al., 2020). Egy kiváló és gyorsan felvehető eszköz a testdiszmorfiás zavar szűrésére a kilenc kérdéses BDDQ-DV (Danesh et al., 2015).

Ebben a szekcióban pszichológiai tényezők jelentőségét tárgyaltam a bőrgyógyászatban. Sok kiváló tanulmány készült olyan szemszögből is, hogy a témát „fordítva” vizs- 
gálta: hogy bizonyos bőrbetegségekhez milyen pszichés jellemzők kapcsolódnak. Találhatunk ilyen leírásokat többek között a közönséges akne (Stamu-O'Brien et al., 2021), a pikkelysömör (Torales et al., 2020) és a hajbetegségek (Jafferany \& Patel, 2020; Montgomery et al., 2017) témáiból. Ritka bőrbetegségek pszichés oldalával foglalkozó cikkek is hasznosak lehetnek a bőrgyógyászati ellátások számára, mint például: az onychotillomania-nak, melynél a páciens repetitív viselkedésével károsítja saját köröm apparátusát (Sidiropoulou et al., 2019), vagy a dermatitis neglecta-nak, mely az alacsony higiéniai szint következtében kialakult betegség (Lopes et al., 2018), vagy a GardnerDiamond szindrómának, melynél rózsaszín vagy vörös ödémás plakkok jelennek meg a páciensen súlyos stressz megtapasztalását és érzelmi traumát követően, és a betegség bőrgyógyászati, pszichoterápiás és pszichiátriai ellátást is igényelhet (Jafferany \& Bhattacharya, 2015).

\section{AZ EGÉSZSÉGPSZICHOLÓGIAI MUNKA CÉLJAI BŐRBETEGEKNÉL}

Az egészségpszichológiai támogatás céljai nagyon sokfélék lehetnek bőrbetegeknél. Ilyen célkitűzéseket foglal össze a 2 . táblázat.

\begin{tabular}{|l|}
\hline \multicolumn{1}{|c|}{ A pszichológiai támogatás céljai börbetegeknél } \\
\hline Alvási nehézségek azonosítása. \\
\hline A distressz szintjének csökkentése. \\
\hline Pszichiátriai tünetek azonosítása. \\
\hline Társas izoláció csökkentése. \\
\hline Önbecsülés növelése. \\
\hline Segíteni őket betegségük elfogadásában. \\
\hline Felfedezni, hogy milyen kezeléseket választhat a páciens, és segíteni a döntéshozatalt. \\
\hline $\begin{array}{l}\text { Megvizsgálni, hogy milyen nehézségeket tapasztalnak a bőrbetegségük miatt, és belátást } \\
\text { nyerni arról, hogy milyen tényezők tartják fenn ezeket a nehézségeket. }\end{array}$ \\
\hline Azonosítani hasznos megküzdési stratégiákat. \\
\hline Fejleszteni a szociális interakciós készségeket. \\
\hline Megvizsgálni, hogy milyen témák kapcsolódnak indirekt módon a bőrbetegséghez. \\
\hline
\end{tabular}

2. táblázat: A pszichológiai támogatás céljai bőrbetegeknél (Jafferany \& Franca, 2016; Papadopoulos, 2005 nyomán).

\section{SZAKMÁK KÖZÖTTI EGYÜTTMÛ́KÖDÉS}

Walker (2005) szerint kevés bőrgyógyász előfizetője egészségpszichológiai folyóiratoknak, és kevés pszichológus követi a legújabb eredményeket bőrgyógyászati kiadványokban. A pszichodermatológia mintha az élettani és a pszichoszociális kutatások közé szorult volna a múltban a publikálás terén. A különböző szempontok ötvözésére volt 
szükség ahhoz, hogy a pszichodermatológiai kutatások eljussanak akadémiai és gyógyítói munkakörökben dolgozó olvasókhoz (Walker, 2005).

Ma sokan vélekednek úgy a pszichodermatológiával foglalkozók körében, hogy a lelki tényezők szempontjából kiemelten érintett páciensek ellátásában fontos a bőrgyógyászok és pszichiáterek mellett a pszichológusok munkája is (Azambuja, 2017; Kálmán et al., 2014; Patel \& Jafferany, 2020; Šitum et al., 2016). Marshall és munkatársai (2016) részletes leírást készítettek arról, hogy milyen szakemberek együttműködésére lehet szükség a pszichodermatológiai gyógyító munkában: bőrgyógyászra, pszichiáterre, pszichológusra, bőrgyógyászati ápolóra, gyermek-és serdülőkorra specializált mentálhigiénés szakemberre, gyermekorvosra, geriáter szakorvosra, szociális munkásra, trichológusra (hajgyógyászra), háziorvosra, gyermekvédelmi és kiszolgáltatott felnőtteket védő csoportra, beteg érdekképviseleti és betegtámogató csoportra.

Finlay és munkatársai (2021) az EADV (European Academy of Dermatology and Venereology) munkacsoportjaként összegyűjtöttek olyan módszereket, amelyek segíthetnek bőrbetegeknek, akik kaptak kezelést, de mégis életminőség-romlás jeleit mutatják. Négy csoportra bontották az életminőséget javító módszereket, tényezőket: börgyógyászati beavatkozások (kórházi kezelés, multidiszciplináris csoportok bevonása, patch tesztek használata, valamint a releváns allergének meghatározása, oktatás); külsö szolgáltatások (korrekciós smink, klimatoterápia és balneoterápia); pszichológiai módszerek (pszichológiai beavatkozás, kognitív terápia, hipnózis); életmód (életmódbeli viselkedésbeli változások, vallásgyakorlás, spiritualitással foglalkozás és zenehallgatás) (Finlay et al., 2021). A munkacsoport szerint a klinikusoknak mérlegelniük kell ezen megközelítések alkalmazását, ha az életminőség a szokásos terápia optimális alkalmazása ellenére is romlik egy adott páciensnél (Finlay et al., 2021).

Papadopoulos (2005) a következő pszichoterápiás irányzatok eszközeinek alkalmazását ajánlotta a bőrbetegek pszichológiai jóllétének és életminőségük növelése érdekében: viselkedésterápia, kognitív viselkedésterápia, csoportterápia, pszichoanalízis. Ezekkel a módszerekkel klinikailag jelentős változásokat értek el pikkelysömörrel, ekcémával, vitiligo-val (mely krétafehér színű, változatos alakú és méretủ foltok megjelenésével jár /Kárpáti et al., 2019/), aknéval kezelt pácienseknél (Papadopoulos, 2005). Emellett hatékonynak bizonyult még a biofeedback (Piaserico et al., 2016) és a relaxációs terápia pikkelysömörnél (Neerackal et al., 2020), hipnoterápia „terápiarezisztens” foltos hajhullásnál (Willemsen et al., 2011), és progresszív izomrelaxáció atópiás dermatitisznél (Bae et al., 2012). Skurya és munkatársai (2020) szerint a kognitív viselkedésterápia tudatos jelenlét (mindfulness) alapú módszerekkel is hatékony lehet testre irányuló repetitív viselkedészavarnál alkalmazva. Harth és munkatársai (2009) az előbbieken túl ajánlották bőrbetegeknek az aktív imaginációt, a légzésterápiát, a családterápiát, a Feldenkrais módszert (mozgásterápia), személyközpontú pszichoterápiát, Gestalt terápiát, kreatív terápiákat (művészetterápia, zeneterápia), katatím imaginatív pszichoterápiát, koncentratív mozgásterápiát, neuro-lingvisztikus programozást és tranzakcióanalízist. 


\section{GYAKORLATI TAPASZTALATOK BEMUTATÁSA}

\subsection{EGÉSZSÉGPSZICHOLÓGIAI TÁMOGaTÁS A BőRGYóGÝ́SZATBAN}

11 évet dolgoztam az SZTE Bőrgyógyászati és Allergológiai Klinika alkalmazásában, és ez alatt a klinikán ambuláns pácienseket és fekvőbetegeket is részesítettem egészségpszichológiai támogatásban. A munkatémák, az ülésszámok, és az üléssorozatok megvalósult szakmai céljai igen eltérőek lehetnek bőrbetegeknél, ennek szemléltetésére emeltem ki záróüléseken elhangzott véleményeket a közös munkákról a 3. táblázatba.

\begin{tabular}{|c|c|c|}
\hline Kiemelések & $\begin{array}{l}\text { A páciens } \\
\text { jellemzői }\end{array}$ & $\begin{array}{l}\text { Ülés- } \\
\text { szám }\end{array}$ \\
\hline $\begin{array}{l}\text { Hogy a pikkelysömör mint lelki páncél, erről nem tudom, hogy } \\
\text { mit gondoljak. Viszont az, hogy foglalkoztunk az álmokkal, az } \\
\text { abszolút megvilágította számomra a pikkelysömör lelki oldalait. } \\
\text { Nem tudom, hogy a terápiánk vagy a kezelés hatása is ez, de úgy } \\
\text { érzem, hogy most teljesen tünetmentes vagyok. Úgy érzem, hogy } \\
\text { sokkal nagyobb rálátásom van a pikkelysömörömmel kapcsolatos } \\
\text { lelki tényezőkre. Köszönöm ezeket a beszélgetéseket. }\end{array}$ & $\begin{array}{l}\text { Pikkelysömörrel } \\
\text { kezelt nő. }\end{array}$ & 6. \\
\hline $\begin{array}{l}\text { Sok területen érzékeltem változást a beszélgetéseink hatására, } \\
\text { például abban, hogy máshogy viszonyulok családtagokhoz. } \\
\text { Nem húztam fel magam azon, hogy kaptam parkolócédulát, } \\
\text { ezt változásnak tekintem. Úgy látom, hogy ezek a beszélgetések } \\
\text { megalkotják annak az alapját, hogy nyugodtan, átgondoltan ül- } \\
\text { hessek be ide ilyenkor, és átlássak bizonyos dolgokat, folyama- } \\
\text { tokat. Megnyugtatnak ezek az ülések. Jó az, hogy van egy biz- } \\
\text { tos hely, ahova el tudok jönni foglalkozni a dolgaimmal, és } \\
\text { hogy kibeszélhetem magam, az jó hatással van rám. }\end{array}$ & $\begin{array}{l}\text { Orbánccal } \\
\text { kezelt férfi. }\end{array}$ & 8. \\
\hline $\begin{array}{l}\text { Megkönnyebbültem az üléseken. Ne stresszelj. Fogd fel lazán. } \\
\text { Ne így reagálj, hanem amúgy. Tudatosultak dolgok. } 10 \text { kg-ot le } \\
\text { kellene fogynom. Erre valamit ki kéne találnom. Börgyógyá- } \\
\text { szommal jók a tapasztalataim. }\end{array}$ & $\begin{array}{l}\text { Pikkelysömörrel } \\
\text { kezelt nő. }\end{array}$ & 5. \\
\hline $\begin{array}{l}\text { Hasznosak voltak ezek az ülések... olyan dolgokról tudtam be- } \\
\text { szélni, amikről nem szoktam... olyanok, amikről kevés ember- } \\
\text { nek beszélek... munkahelyen persze beszélgetünk a többiekkel, } \\
\text { de ott inkább munkahelyi témákról. }\end{array}$ & $\begin{array}{l}\text { Bőrre lokalizált } \\
\text { vasculitis-szel } \\
\text { (érgyulladás) } \\
\text { kezelt nő. }\end{array}$ & 6. \\
\hline $\begin{array}{l}\text { Itt nyugalom van, itt rám van figyelve. El tudom képzelni, } \\
\text { hogy kapaszkodót jelentsen nekem az üléssorozat, mint egy elö- } \\
\text { adás... kell, hogy leülepedjen. Köszönöm az őszinte véleményt. }\end{array}$ & $\begin{array}{l}\text { Pikkelysömörrel } \\
\text { kezelt nő. }\end{array}$ & 6. \\
\hline $\begin{array}{l}\text { Számomra nehezebbek ezek a helyzetek, a magánéletiek, mint } \\
\text { azok, amikor betegségem van vagy mütétre kell jönnöm, mert ar- } \\
\text { ra van megoldás, ezekre viszont nincs... minden fejben dől el. } \\
\text { Talán az egy lehetőség lehet, hogy több emberben bízzak meg? }\end{array}$ & $\begin{array}{l}\text { Allergiával } \\
\text { kezelt nő. }\end{array}$ & 7. \\
\hline
\end{tabular}




\begin{tabular}{|l|l|l|}
\hline $\begin{array}{l}\text { Felszabadultságot tapasztaltam. Jó volt elmondani. Mint megfür- } \\
\text { deni, amikor az ember kilép a kádból, és lepereg róla a sok kosz. }\end{array}$ & $\begin{array}{l}\text { Pikkelysömörrel } \\
\text { kezelt nő. }\end{array}$ & 12. \\
\hline $\begin{array}{l}\text { Meg kell tanulnom segítség nélkül intéznem dolgokat, hogy ke- } \\
\text { vesebb lépcsőzés mellett többet sétáljak például... vagy, hogy } \\
\text { alacsonyabb lakásba költözzek. Nőtt az önismeretem... rájöt- } \\
\text { tem, hogy nem gondolom magamat hisztisnek. Fitt voltam ré- } \\
\text { gebben, lassítanom kéne. Jelenlegi célom, hogy kicsit én kerül- } \\
\text { jek előtérbe, például sok helyre rohangálás helyett. }\end{array}$ & $\begin{array}{l}\text { Artrózissal } \\
\text { (ízületi } \\
\text { porckopás) } \\
\text { kezelt nő. }\end{array}$ & 10. \\
\hline
\end{tabular}

3. táblázat: kiemelések páciensektől az SZTE ÁOK Bőrgyógyászati és Allergológiai Klinikán egészségpszichológiai támogató üléssorozatok záróüléseiről.

\subsection{ESETBEMUTATÁS ÉS AJÁNLÁSOK AZ ESETVEZETÉSHEZ}

Egy fiktív eset bemutatásával szeretnék rávilágítani néhány fontos témára bőrbetegek pszichés támogatása kapcsán.

Károllyal kapcsolatosan bőrgyógyásza keresett meg engem, a fiatal férfit az SZTE ÁOK Bőrgyógyászati és Allergológiai Klinikán kezelik ambulánsan pikkelysömörrel. Bőrgyógyásza számára Károly demotiváltnak, fáradtnak tünik, ami a kezelőorvos szerint befolyással van tünetei alakulására. A páciens 22 éves, a pikkelysömör először 18 éves korában jelent meg nála, amikor Szegedről, a szülői házból Budapestre költözött albérletbe. Tünetei eleinte (vörös színű, fehéren hámló plakkok) végtagjai külső felszínén, könyökeinél, térdeinél, és a hajas fejbőrén jelentkeztek. Korábban helyi készítményeket, krémeket kapott kezelés céljából, majd tünetei súlyosbodásakor fénykezelést is kapott. Mostanában nehéz elérni betegsége remisszióját. A viszketés kellemetlenséget okoz számára, amely leginkább éjszaka lép fel nála, van, hogy akár kétszer-háromszor is felébred a viszketés miatt. Károly Szegeden született, jelenleg egyetemen tanul Budapesten. A Moholy-Nagy Művészeti Egyetem Kerámia BA szakát elvégezte, és jelenleg a Kerámia MA képzés másodéves hallgatója. Introvertáltnak írja le magát, lassan beszél. Két éve ért véget egy három hónapos kapcsolata, melyben egy hozzá hasonló kórú budapesti nővel voltak együtt, és exbarátnője elmondása szerint azért szakított vele, mert unalmasnak tartotta Károly viselkedését. Jelenleg a Tinder applikációval próbál ismerkedni. Megterhelő számára érzelmileg látni, ahogy kortársai párkapcsolatokba léptek az utóbbi hónapokban, miközben számára nehéz az ismerkedés. A bőrtünetek hatással vannak önbecsülésére is. A koronavírus-járványhelyzet miatt hazaköltözött a szülői házba Szegedre 15 hónappal ezelőtt, az egyetemet online végzi. Szülei támogatják, de szokatlan neki, hogy otthonról vesz részt az oktatásban. Amikor ismerőseivel teniszezni mentek, az öltözőben furcsán néztek rá néhányan pikkelysömörös tünetei miatt. Nehéz egyetemi feladataira fókuszálni a pikkelysömör okozta olykori szúró, viszkető érzések miatt. Tapasztalt olyat egyetemi kortársainál, hogy nem mertek vele kezet fogni, mert attól féltek, hogy a tünetei fertőzőek. Elmondta, hogy fél a szisztémás kezelésektől, amelyekről konzultáltak bőrgyógyászával, és elfogadja, hogy bizonyos esetekben orvo- 
silag indokolt az alkalmazásuk, de mégis ijesztőnek tartja őket. Károly szerint a beletörődő attitűdje miatt gondolta bőrgyógyásza, hogy demotivált a kezelésében, mert egyébként betartja a dermatológiai ellátásával kapcsolatos teendőket. Gimnáziumában az iskolapszichológus feliratot nézte az egyik ottani helyiség ajtaján, és elképzelte milyen lenne bemenni oda, de mégsem kért időpontot. Azt mondta az első egészségpszichológiai konzultáción, hogy „ez jó volt, lehet, hogy a legközelebbi ülés még jobb lesz”. A temperamentumról hallott pszichológushallgató ismerősétől, aki „lassan felmelegedő” temperamentumot vélt nála felfedezni. Károly édesapja festőművész, édesanyja történelemtanár.

\subsubsection{A TÁMOGATÁS ALAPVETő JELLEGE}

Alapvetően különbözhet az egészségpszichológiai támogatás jellege, ha fekvőbeteggel, vagy ha járóbeteggel dolgozunk. Fekvőbetegnél fontos lehet, hogy ne a tünetek hátterében meghúzódó tényezők feltárása legyen az elsődleges szempont, hanem egy úgynevezett elsődleges tapasztalati tér kialakítása (Csabai, 2010). Fontos, hogy biztonságérzetet adjunk egyfajta ritmikusság közvetítésével - például a kórházi történések kiszámíthatóságára vonatkozóan - a pácienshez odafordulás és tükrözés által, és így elérhetjük, hogy a tapasztalatok átélhetőek legyenek, érzések és gondolatok kapcsolódhassanak a történésekhez, majd az érzések verbalizálhatóvá válhatnak a technika által. Járóbetegeknél, ha egészségfejlesztésre van szükség, a motivációs interjú hasznos technika lehet, mellyel segíthetünk egészségviselkedések megváltoztatásában (Urbán, 2017). Ha a páciens lelki támogatása a fó cél, akkor a pszichoszomatikus összefüggésekkel kapcsolatos edukáció és a lelki támogatás, alap-pszichoterápiás jellegü munka hasznos eszközök az egészségpszichológus számára.

Károllyal ambuláns keretek közötti támogatásra kerülhetne sor, például a következő fókuszpontokkal: önismeret fejlesztésével (akár gyorsan felvehető személyiségteszt felvételével, például a Goldberg (1992) markerek 50 tételes IPIP-reprezentációjával a BigFive faktorstruktúrának); énképpel és testképpel; fontos személyekhez való viszonyulásaival (akár a PRISM-D rajzteszt (Havancsák et al., 2013) alkalmazásával felmérve), kezeléssel kapcsolatos attitüdjeivel dolgozva.

\subsection{2. ÜLÉSSZÁM}

Fontos lehet, hogy az első ülésen mit mondunk a páciensnek, hány ülésre szerződünk vele. Dalgard és munkatársai (2020) egy svédországi pszichodermatológiai ellátóegység egyéves periódusában ellátott 50 páciens kezeléseit elemezték. Azt állapították meg, hogy aki igénybe vett pszichoterápiás jellegü támogatást, azoknál a pácienseknél a leggyakrabban 1-5 ülést tartottak az egység szakemberei (Dalgard et al., 2020). Roche és munkatársai (2018) egy írországi pszichodermatológiai klinika hétévnyi ellátási adatait elemezték. Az átlagos ülésszám, amelyben pszichoterápiás támogatást nyújtottak az oda 
érkező pácienseknek, 4,3 volt, és 1-16 között mozgott a velük tartott üléssorozatok találkozásainak száma (Roche et al., 2018). Urbán (2017) azt javasolta, hogy klinikai egészségpszichológiai munka során egészségi állapotot veszélyeztető viselkedés esetén, a viselkedésváltozások intenzív támogatásához 3-6 ülés szükséges lehet. Mindezek alapján azt a következtetést vonom le, hogy bőrgyógyászati ambuláns páciens számára 6 üléses találkozássorozat javasolható az első konzultáció alkalmával. Ezt az ülésszámot Károly számára is javasolhatnánk az első találkozáskor.

\subsubsection{ELSŌ TALÁLKOZÁS A PÁCIENSSEL}

Érdemes lehet pszichoszomatikus első interjút felvenni a bőrbetegekkel. Ennek fontos elemei, hogy az interjúalany betegségtörténetében lelki történések esetleges összefüggéseit szomatikus adatokkal úgy térképezi fel a szakember, hogy lehetőséget ad arra, hogy a páciens azokat saját szavaival, nagymértékben a neki tetsző sorrendben és időpontban mondhassa el (Adler, 1999). Az interjúséma a következő: 1. bemutatkozás; 2. lehetőség szerint kényelmes körülmények biztosítása a beszélgetéshez; 3. (nyitott kérdésekkel érdeklődve) panaszok és az orvoshoz fordulás oka; 4. az aktuális panaszok taglalása (a. időbeli fellépésük, b. jellegük, c. intenzitásuk, d. lokalizációjuk, e. összefüggésük más panaszokkal, f. jelentkezésük körülményei, g. fokozódásuk és enyhülésük jellemzői); 5. esetleges korábbi betegségek; 6. hozzátartozók egészségi állapota; 7. személyes fejlödés; 8. jelenlegi életkörülmények; 9. szisztematikus rákérdezés más szervrendszerek tüneteire; 10. a páciens kérdései, kiegészítései (Adler, 1999). A pszichoszomatikus interjútechnikát Tomas-Aragones és munkatársai (2017) bőrgyógyászoknak is ajánlották, mivel az feltérképezi a páciens által mondottak biomedikális, pszichológiai és szociokulturális szempontjait. Ennek az interjús formának az alkalmazása orvosok és pszichológusok számára is hasznos lehet.

Károly esetében a pszichoszomatikus interjútechnika alkalmazása fóként azzal az előnnyel járhatna, hogy új megvilágításba kerülhetne, hogy pszichofiziológiai típusú bőrbetegsége (pikkelysömör) tüneteire milyen hatással lehet a pszichés distressz.

\subsubsection{A BETEG TÁMOGATÁSÁT ÉRINTŐ TÉNYEZŐK}

Miközben klinikai egészsépszichológiai ülést tartunk, érdemes ügyelnünk a verbalizációnkra és a páciens önfeltárásának mértékére. Fontos, stabil összefüggés áll fenn kutatások szerint a szakember verbalizációja és a páciens önexplorációja között: az üléssorozat verbalizációs szintje hatással van az önexploráció mértékére és fordítva (Tringer, 2007).

Hogy milyen témákkal dolgozhatnánk Károllyal, az a páciens igényeitől is függene, de az esetbemutatás alapján a következők kerülhetnek megbeszélésre az első ülésen: hangulati állapota, szociális hálója jellemzői, pszichoszomatikus összefüggések stresszteli helyzetek és bőrállapota között, betegségreprezentációi, az orvos-beteg együttmüködés jellemzői, alvásminőség, viszonyulása a szakmájához és az egyetemi képzéséhez, kötő- 
dési mintázata, személyiségjellemzői, a koronavírus-járványhelyzet lelki hatásai, stigmatizációs élmények a tünetei miatt, családi szokásaik, pszichológiai támogatással kapcsolatos elvárásai.

\section{Mire tanít ez az eset?}

A 3. táblázatban olvasható „megvalósult” pszichológiai célokat megnézve érdekesnek tartottam szakmailag, hogy néha hasonlóképpen láttam, hogy mit nyert az üléssorozatból a páciens, néha megleptek az elhangzott mondatok egy-egy záróülésen. Gondolkodásmódomra a lelki támogatásról erős hatással volt az, hogy három évig az SZTE ÁOK és BTK Alkalmazott Egészségpszichológiai Szakpszichológus Szakképzés központi gyakornoka voltam, és hogy négy évig képződtem a MASZKPTE Személyközpontú pszichoterápiás módszerspecifikus képzésén. Hallani azt, hogy egyes pácienseknek fontos személyekhez kapcsolódási módjai változtak, mások személyiségműködése akár a Carl Rogers nevéhez füződ” „teljesen működő személy” (Rogers, 1963) képéhez közelebb került, és megint mások pedig a bőrbetegségük pszichoszomatikus összefüggéseinek átlátásáról számoltak be, sokszínűvé tette a szememben a bőrbetegekkel folytatott egészségpszichológiai támogatást.

\section{KIHÍVÁSOK ÉS FEJLŐDÉSI LEHETŐSÉGEK A PSZICHODERMATOLÓGIÁBAN}

Mint azt láthattuk, a pszichodermatológia tudománya és alkalmazási területe sok változáson ment keresztül az utóbbi évtizedekben. Végezetül néhány új fejlődési lehetőséget, irányvonalat és jó gyakorlatot ismertetek a lélek és a bőr kapcsolódásait illetően.

Zhang és munkatársai (2021) kifejlesztették a Pszichoszociális Adaptáció Kérdőívet krónikus bőrbetegek vizsgálatához. A 321 bőrbeteg által tesztelt 18 itemes skála három faktort vizsgál: a páciens pszichoszociális adaptációjának lelki (pl. a bőrproblémák tehetetlenné teszik-e), társas (pl. mások bántó megjegyzéseket tesznek-e a bőrbetegségére) és kognitív oldalait (pl. összességében elégedett-e magával). A szerzők szerint a skála egy forgalmas bőrgyógyászati rendelésen is felvehető, és kiegészítheti a bőrgyógyászati életminőség vizsgálatokat (Zhang et al., 2021).

Ryan és Wagner (2021) szerint érdemes lenne az Egyesült Államokban rezidensképzésüket éppen elvégzett bőrgyógyászoknak és pszichiátereknek egyéves pszichodermatológiai ösztöndíjat alapítani, mely jó hatással lenne a páciensekre, a szakemberekre és az orvosi karra is. Hewitt és munkatársai (2021) egy motivációs interjút és pikkelysömörnél viselkedésváltozást segítő egynapos, szakembereknek tartott tréning hatásait vizsgálták az Egyesült Királyságban. A tréningen részt vettek több szakma képviselői, bőrgyógyászok, pszichológusok, ápolók is, és beszámolóik szerint ez növelte készségei- 
ket, magabiztosságukat és motivációjukat pácienseik viselkedésváltozásának támogatásához (Hewitt et al., 2021). A németországi Kiel városában az egyetemi bőrgyógyászati részleghez tartozó orvostanhallgatóknak szervezett oktatási program keretében tartottak pszichodermatológiai szemináriumokat 2018-2020 között, amelyek során a hallgatóknak lehetőségük volt megismerkedni a bőrbetegség okozta stressz és a biopszichoszociális betegségmodell témáival (Wittbecker et al., 2021). Szegeden az SZTE ÁOK Magatartástudományi Intézet szervezésében zajlik oktatás pszichodermatológiáról orvostanhallgatóknak a „Pszichoszomatikus-integratív medicina elmélete és gyakorlata” kurzus keretein belül.

Az oktatás az ellátáson belüli szakmai együttmüködés lehetőségét teremti meg, mely különösen fontos a pszichodermatológia területén. Ebbe az irányba mutató kezdeményezések a pszichodermatológiai klinikák, egységek, melyek nemzetközi tekintetben több országban is megalakultak, mint például Izraelben (Orion \& Ben-Avi, 2011; Orion et al., 2012), Indiában (Goyal et al., 2018; Shenoi \& Prabhu, 2018), Szingapúrban (Chung et al., 2012), az Egyesült Államokban (Seale et al., 2018), Portugáliában (Ferreira et al., 2019). Magyarországon a szegedi Bőrgyógyászati és Allergológiai Klinikán három szakember nyújt egészségpszichológiai támogatást és végez kutatásokat ezen a rendkívül sokszínű ellátási területen.

\section{IRODALOM}

Adamo, D., Ruoppo, E., Leuci, S., Aria, M., Amato, M., Mignogna, M. D. (2015). Sleep disturbances, anxiety and depression in patients with orallichenplanus: a case-control study. The Journal of the European Academy of Dermatology and Venereology, 29(2), 291-297.

Adler, R. (1999). Anamnézis és az első interjú a pszichoszomatikus orvoslásban (I. Tiringer, Trans.). In J. Kállai, B. Gál (Eds.), Az elsö találkozás jelenségvilága a segitö kapcsolatban (pp. 53-80). Janus Pannonius Tudományegyetem/Osiris könyvek.

Azambuja, R. D. (2017). The need of dermatologists, psychiatrists and psychologists joint care in psychodermatology. Anais Brasileiros de Dermatologia, 92(1), 63-71.

Bäckström, M., Holmes, B. M. (2001). Measuring adult attachment: a construct validation of twoself-report instruments. Scandinavian Journal of Psychology, 42(1), 79-86.

Bae, B. G., Oh, S. H., Park, C. O., Noh, S., Noh, J. Y., Kim, K. R., Lee, K. H. (2012). Progressive muscle relaxation therapy for atopic dermatitis: objective assessment of efficacy. Acta Dermato-Venereologica, 92(1), 57-61.

Barbosa, F., Freitas, J., Barbosa, A. (2011). Alexithymia in chronicurticariapatients. Psychology, Health \& Medicine, 16(2), 215-224.

Bartholomew, K., Horowitz, L. M. (1991). Attachment styles among young adults: a test of a four-category model. Journal of Personality and Social Psychology, 61(2), 226-244.

Bowlby, J. (1977). The making and breaking of affectionalbonds: I. Aetiology and psychopathology in thelight of attachmenttheory. The British Journal of Psychiatry, 130, 201-210. 
Chung, W. L., Ng, S. S., Koh, M. J., Peh, L. H., Liu, T. T. (2012). A review of patients managed at a combined psychodermatology clinic: a Singapore experience. Singapore Medical Journal 53(12), 789-793.

Csabai, M. (2010). Bálint és a pszichoszomatika. Tárgykapcsolati elvek a testi tünetek kezelésében. Thalassa, 21(2), 33-48.

Dalgard, F. J., Bewley, A., Evers, A. W., Gieler, U., Lien, L., Sampogna, F., Stander, S., Tomas-Aragones, L., Vulink, N., Kupfer, J. (2018). Stigmatisation and body image impairment in dermatologicalpatients: protocolfor an observational multicentre study in 16 European countries. BMJ Open, 8(12), e024877. 10.1136/bmjopen-2018-024877

Dalgard, F. J., Gieler, U., Tomas-Aragones, L., Lien, L., Poot, F., Jemec, G. B. E., Misery, L., Szabo, Cs., Linder, D., Sampogna, F., Evers, A. W. M., Halvorsen, J. A., Balieva, F., Szepietowski, J., Romanov, D., Marron, S. E., Altunay, I. K., Finlay, A. Y., Salek, S. S., Kupfer, J. (2015). The psychological burden of skin diseases: a cross-sectional multicenter study among dermatological out-patients in 13 European countries. The Journal of Investigative Dermatology, 135(4), 984-991.

Dalgard, F. J., Sjöström, K., Fhager, J., Svensson, Å, Wallin, E., Hauksson, I. (2020). Subjective and Objective Characteristics of Patients Seenat a Psychodermatology Unit: One-year Experience in Malmö, Sweden. Acta Dermato-Venereologica, 100(8), adv00126. 10.2340/ 00015555-3460

Danesh, M., Beroukhim, K., Nguyen, C., Levin, E., Koo, J. (2015). Body dysmorphic disorder screening tools for the dermatologist: A systematic review. Practical Dermatology, 2, 44-49.

Dieris-Hirche, J., Milch, W. E., Kupfer, J., Leweke, F., Gieler, U. (2012). Atopicdermatitis, attachment and partnership: a psychodermatological case-control study of adult patients. Acta Dermato-Venereologica, 92(5), 462-466. 10.2340/00015555-1374

Dixon, L. J., Witcraft, S. M., McCowan, N. K., Brodell, R. T. (2018). Stress and skin disease quality of life: the moderating role of anxiety sensitivity social concerns. British Journal of Dermatology, 178(4), 951-957.

Esposito, M., Giunta, A., Nanni, R. C., Criscuolo, S., Manfreda, V., DelDuca, E., Bianchi, L., Troisi, A. (2020). Depressive symptoms and insecure attachment predict disability and quality of life in psoriasis independently from disease severity. Archives of Dermatological Research. 10.1007/s00403-020-02116-8

Ferreira, B. R., Jafferany, M. (2021). Classification of psychodermatological disorders. Journal of Cosmetic Dermatology, 20(6), 1622-1624.

Ferreira, B. R., Pio-Abreu, J. L., Reis, J. P., Figueiredo, A. (2019). First psychodermatology clinic in a Portuguese Department of Dermatology. The Journal of the European Academy of Dermatology and Venereology, 33(3), e119-e120. 10.1111/jdv.15303

Finlay, A. Y., Chernyshov, P. V., Tomas Aragones, L., Bewley, A., Svensson, A., Manolache, L., Marron, S., Suru, A., Sampogna, F., Salek, M. S., Poot, F. (2021). Methods to improve quality of life, beyond medicines. Position statement of the European Academy of Dermatology and Venereology Task Force on Quality of Life and Patient Oriented Outcomes. The Journal of the European Academy of Dermatology and Venereology, 35(2), 318-328. 10.1111/jdv.16914

França, K., Castillo, D. E., Roccia, M. G., Lotti, T., Wollina, U., Fioranelli, M. (2017). Psychoneurocutaneous medicine: past, present and future. Wiener Medizinische Wochenschrift, 167(Suppl 1), 31-36. 
França, K., Chacon, A., Ledon, J., Savas, J., Nouri, K. (2013). Pyschodermatology: a trip through history. Anais Brasileiros de Dermatologia, 88(5), 842-843.

Gieler, U., Gieler, T., Peters, E. M. J., Linder, D. (2020). Skin and Psychosomatics - Psychodermatology today. Journal der Deutschen Dermatologischen Gesellschaft, 18(11), 1280-1298.

Goldberg, L. R. (1992). The development of markersforthe Big-Five factor structure. Psychological Assessment, 4, 26-42.

Goyal, N., Shenoi, S., Prabhu, S. S., Sreejayan, K., Munoli, R., Rai, S. (2018). Psychodermatology liaison clinic in India: a workingmodel. Tropical Doctor, 48(1), 7-11.

Gupta, M. A., Gupta, A. K. (2013). A practical approach to the assessment of psychosocial and psychiatric comorbidity in the dermatology patient. Clinics in Dermatology, 31(1), 57-61.

Halioua, B., Sid-Mohand, D., Roussel, M. E., Maury-le-Breton, A., de Fontaubert, A., Stalder, J. F. (2016). Extent of misconceptions, negative prejudices and discriminatory behaviour to psoriasis patients in France. The Journal of the European Academy of Dermatology and Venereology, 30(4), 650-654.

Harth, W., Gieler, U., Kusnir, D., Tausk, F. A. (2009). Clinical Management in Psychodermatology. Springer Science \& Business Media.

Havancsák, R., Pócza-Véger, P., Csabai, M. (2013). A PRISM-D rajzteszt kórházi betegek vizsgálatában és kezelésében. In M. Csabai, J. N. Pintér (Eds.), Pszichológia a gyógyitásban (pp. 83-107). Oriold és Társai Kiadó.

Hawro, T., Hawro, M., Zalewska-Janowska, A., Weller, K., Metz, M., Maurer, M. (2020). Pruritus and sleep disturbances in patients with psoriasis. Archives of Dermatological Research, 312(2), 103-111.

Hawro, M., Maurer, M., Weller, K., Maleszka, R., Zalewska-Janowska, A., Kaszuba, A., Gerlicz-Kowalczuk, Z., Hawro, T. (2017). Lesions on the back of hands and female gender predispose to stigmatization in patients with psoriasis. The Journal of the American Academy of Dermatology, 76(4), 648-654 e642. 10.1016/j.jaad.2016.10.040

Hazan, C., Shaver, P. (1987). Romantic love conceptualized as an attachment process. Journal of Personality and Social Psychology, 52(3), 511-524.

Hewitt, R. M., Pattinson, R., Cordingley, L., Griffiths, C. E. M., Kleyn, C. E., McAteer, H., Schofield, J., Bundy, C. (2021). Implementation of the PsoWell ${ }^{\mathrm{TM}}$ Model for the Management of People with Complex Psoriasis. Acta Dermato-Venereologica, 101(4), adv00445. 10.2340/00015555-3802

Hiebler-Ragger, M., Unterrainer, H. F., Thompson, A. R., Kellett, S., Aberer, E. (2020). [German version of the Skin Shame Scale (SSS-24):Validation with dermatological patients and dermatologically healthy individuals]. Hautarzt, 71(2), 124-129.

Homayoon, D., Hiebler-Ragger, M., Zenker, M., Weger, W., Unterrainer, H., Aberer, E. (2020). Relationship Between Skin Shame, Psychologica IDistress and Quality of Life in Patients with Psoriasis: a Pilot Study. Acta Dermato-Venereologica, 100(14), adv00205. $10.2340 / 00015555-3563$

Jafferany, M. (2007). Psychodermatology: a guide to understanding common psychocutaneous disorders. Primary Care Companion to the Journal of Clinical Psychiatry, 9(3), 203-213.

Jafferany, M., Afrin, A., Mkhoyan, R., Khemani, U., Sadoughifar, R. (2020). Therapeutic implications of personality disorders in dermatology. Dermatologic Therapy, 33(6), e13910. $10.1111 /$ dth. 13910 
Jafferany, M., Bhattacharya, G. (2015). Psychogenic Purpura (Gardner-Diamond Syndrome). The Primary Care Companionfor CNS Disorders, 17(1). 10.4088/PCC.14br01697

Jafferany, M., Ferreira, B. R., Abdelmaksoud, A., Mkhoyan, R. (2020). Management of psychocutaneous disorders: A practical approach for dermatologists. Dermatologic Therapy, 33(6), e13969. 10.1111/dth.13969

Jafferany, M., Franca, K. (2016). Psychodermatology: Basics Concepts. Acta DermatoVenereologica, 96(217), 35-37.

Jafferany, M., Patel, A. (2020). Trichopsychodermatology: The Psychiatric and Psychosocial Aspects of Hair Disorders. Dermatologic Therapy, 33(1), e13168. 10.1111/dth.13168

Kálmán, L. J., Gonda, X., Kemény, L., Rihmer, Z., Janka, Z. (2014). A pikkelysömör és a stressz közötti összefüggés pszichológiai és biológiai alapjai. Orvosi Hetilap, 155(24), 939- 948.

Karia, S. B., De Sousa, A., Shah, N., Sonavane, S., Bharati, A. (2015). Psychiatric morbidity and quality of life in skin diseases: A comparison of alopeciaareata and psoriasis. Industrial Psychiatry Journal, 24(2), 125-128.

Kárpáti, S., Gyulai, R., Kemény, L., Remenyik, É., Sárdy, M. (2019). Börgyógyászat és venerológia (2. javitott, bövitett kiadás. Medicina Könyvkiadó Zrt.

Koo, J. Y. M., Lee, C. S. (2003). General approach to evaluating psychodermatological disorders. In J. Y. M. Koo, C. S. Lee (Eds.), Psychocutaneous medicine (pp. 1-12). Marcel Dekker.

Kotekoglu, D., Parlakdag, A., Koramaz, F. S., Varol, G., Aslankoc, V., Bozkurt, S., Memis, C., Karakas, A. A., Alpsoy, E. (2020). Internalized stigma in acnevulgaris and its relationship with quality of life, general health, body perception, and depression. Nigerian Journal of Clinical Practice 23(9), 1289-1294.

Kowalewska, B., Jankowiak, B., Cybulski, M., Krajewska-Kułak, E., Khvorik, D. F. (2021). Effect of Disease Severity on the Quality of Life and Sense of Stigmatization in Psoriatics. Clinical, Cosmetic and Investigational Dermatology, 14, 107-121.

Kurd, S. K., Troxel, A. B., Crits-Christoph, P., Gelfand, J. M. (2010). The risk of depression, anxiety, and suicidality in patients with psoriasis: a population-based cohort study. Archives of Dermatology, 146(8), 891-895.

Lawrence, J. W., Fauerbach, J. A., Heinberg, L. J., Doctor, M., Thombs, B. D. (2006). The reliability and validity of the Perceived Stigmatization Questionnaire (PSQ) and the Social Comfort Questionnaire (SCQ) among an adult burn survivor sample. Psychological Assessment, 18(1), 106-111.

Lopes, S., Vide, J., Antunes, I., Azevedo, F. (2018). Dermatitisneglecta: a challenging diagnosis in psychodermatology. Acta Dermatovenerologica Alpina Pannonicaet Adriatica, 27(2), 109- 110.

Marron, S. E., Miranda-Sivelo, A., Tomas-Aragones, L., Rodriguez-Cerdeira, C., TriboBoixaro, M. J., Garcia-Bustinduy, M., Gracia-Cazana, T., Ros-Abarca, S., Roe-Crespo, E., Diaz-Díaz, R. M., Brufau-Redendo, C., Martinez-Gonzalez, M. C., Guerra-Tapia, A., González-Guerra, E., Puig, L. (2020). Body dysmorphic disorder in patients with acne: a multicentre study. The Journal of the European Academy of Dermatology and Venereology, 34(2), 370-376.

Marshall, C., Taylor, R., Bewley, A. (2016). Psychodermatology in Clinical Practice: Main Principles. Acta Dermato-Venereologica, 96(217), 30-34. 
Martín-Brufau, R., Romero-Brufau, S., Martín-Gorgojo, A., BrufauRedondo, C., Corbalan, J., Ulnik, J. (2015). Psoriasis lesions are associated with specific types of emotions. Emotional profile in psoriasis. The European Journal of Dermatology, 25(4), 329-334.

Matiushenko, V., Kutasevych, Y., Jafferany, M. (2020). Neurotransmitter imbalance in serum of psoriatic patients in exacerbation stage with comorbid psychoemotional disorders. Dermatologic Therapy, 33(3), e13337. 10.1111/dth.13337

Mavrogiorgou, P., Mersmann, C., Gerlach, G., Herpertz, S., Juckel, G. (2020). Skin Diseases in Patients with Primary Psychiatric Disorders. Psychiatry Investigation, 17(2), 157-162.

Miniszewska, J. (2007). Personal resources as determinants of quality of life in psoriasis patients [Doctoral dissertation, KUL, Lublin].

Montgomery, K., White, C., Thompson, A. (2017). A mixed methods survey of social anxiety, anxiety, depression and wiguse in alopecia. BMJ Open, 7(4), e015468. 10.1136/bmjopen2016-015468

Neerackal, R. J., Abdul Latheef, E. N., Sukumarakurup, S., Jafferany, M. (2020). Relaxation therapy in the management of psoriasis. Dermatologic Therapy, 33(6), e14030. 10.1111/ dth. 14030

Nguyen, T. V., Wong, J. W., Koo, J. (2014). Psoriasis and excessive stress. In T. V. Nguyen, J. W. Wong, J. Koo (Eds.), Clinical cases in psychocutaneous disease, Clinical cases in dermatology (pp. 109-113). Springer-Verlag.

Ograczyk, A., Miniszewska, J., Kępska, A., Zalewska-Janowska, A. (2014). Itch, disease coping strategies and quality of life in psoriasis patients. Postępy Dermatologii i Alergologii, 31(5), 299-304.

Ograczyk, A., Miniszewska, J., Pietrzak, A., Zalewska-Janowska, A. (2017). Sense of coherence as a protective factor in chronicurticaria. Postępy Dermatologii i Alergologii, 34(2), 168-173.

Orion, E., Ben-Avi, O. (2011). [A newpsycho-dermatology clinic in Israel: our first year experience]. Harefuah, 150(1), 9-12, 70.

Orion, E., Feldman, B., Ronni, W., Orit, B. A. (2012). A psychodermatology clinic: the concept, the format, and our observations from Israel. The American Journal of Clinical Dermatology, 13(2), 97-101.

Orion, E., Wolf, R. (2012). Psychological stress and epidermal barrier function. Clinics in Dermatology, 30(3), 280-285.

Papadopoulos, L. (2005). Psychological therapies for dermatological problems. In C. Walker, L. Papadopoulos (Eds.), Psychodermatology: The Psychological Impact of Skin Disorders (pp. 101-115). Cambridge University Press.

Patel, A., Jafferany, M. (2020). Multidisciplinary and Holistic Models of Care for Patients With Dermatologic Disease and Psychosocial Comorbidity: A Systematic Review. JAMA Dermatology, 156(6), 686-694.

Piaserico, S., Marinello, E., Dessi, A., Linder, M. D., Coccarielli, D., Peserico, A. (2016). Efficacy of Biofeedback and Cognitive-behavioural Therapy in Psoriatic Patients A Singleblind, Randomized and Controlled Study with Added Narrow-band Ultraviolet B Therapy. Acta Dermato-Venereologica, 96(217), 91-95.

Roche, L., Switzer, V., Ramsay, B. (2018). A retrospective case series of referralstoour psychodermatology clinic 2009-2016. The Journal of the European Academy of Dermatology and Venereology, 32(7), e278-e279. 10.1111/jdv.14816 
Rodriguez-Vallecillo, E., Woodbury-Fariña, M. A. (2014). Dermatological manifestations of stress in normal and psychiatric populations. Psychiatric Clinics of North America, 37(4), 625-651.

Rogers, C. R. (1963). The concept of the fully functioning person. Psychotherapy: Theory, Research \& Practice, 1(1), 17-26.

Ryan, M. P., Wagner, R. F. (2021). Psychodermatology fellowship: is it time? Dermatology Online Journal, 27(2).

Saad, M., de Medeiros, R., Mosini, A. C. (2017). Are We Ready for a True BiopsychosocialSpiritual Model? The Many Meanings of "Spiritual". Medicines (Basel), 4(4). 10.3390/ medicines 4040079

Scott, C. (2004). Understanding psychodermatological distress: constructing a skin shame scale [Doctor of Clinical Psychology thesis, University of Sheffield].

Seale, L., Gaulding, J. V., Porto, D., Prabhakar, D., Kerr, H. (2018). Implementation of a psychodermatology clinicat a major health system in Detroit. International Journal of Women's Dermatology, 4(4), 227-229.

Shenoi, S. D., Prabhu, S. S. (2018). Psychodermatology: An Indian perspective. Clinics in Dermatology, 36(6), 737-742.

Sidiropoulou, P., Sgouros, D., Theodoropoulos, K., Katoulis, A., Rigopoulos, D. (2019). Onychotillomania: A Chameleon-Like Disorder: Case Report and Review of Literature. Skin Appendage Disorders, 5(2), 104-107.

Šitum, M., Kolić, M., Buljan, M. (2016). [Psychodermatology]. Acta Medica Croatica, 70 (Suppl 1), 35-38.

Skurya, J., Jafferany, M., Everett, G. J. (2020). Habit reversal therapy in the management of body focused repetitive behavior disorders. Dermatologic Therapy, 33(6), e13811. 10.1111/ dth. 13811

Stamu-O'Brien, C., Jafferany, M., Carniciu, S., Abdelmaksoud, A. (2021). Psychodermatology of acne: Psychological aspects and effects of acnevulgaris. Journal of Cosmetic Dermatology, 20(4), 1080-1083.

Szabo, C., Altmayer, A., Lien, L., Poot, F., Gieler, U., Tomas-Aragones, L., Kupfer, J., Jemec, G. B. E., Misery, L., Linder, M. D., Sampogna, F., van Middendorp, H., Halvorsen, J. A., Balieva, F., Szepietowski, J. C., Romanov, D., Marron, S. E., Altunay, I. K., Finlay, A. Y., ... Dalgard, F. (2017). Attachment Styles of Dermatological Patients in Europe: A Multicentre Study in 13 Countries. Acta Dermato-Venereologica, 97(7), 813-818.

Tomas-Aragones, L., Voicu, C., Marron, S. E. (2017). The clinical interview and assessment: general considerations. Romanian Journal of Clinical and Experimental Dermatology: ROJCED, 1(4), 6-13.

Torales, J., Echeverría, C., Barrios, I., García, O., O'Higgins, M., Castaldelli-Maia, J. M., Ventriglio, A., Jafferany, M. (2020). Psychodermatological mechanisms of psoriasis. Dermatologic Therapy, 33(6), e13827. 10.1111/dth.13827

Tringer, L. (2007). A gyógyitó beszélgetés. Gondolat Kiadó.

Urbán, R. (2017). Az egészségpszichológia alapjai. ELTE Eötvös Kiadó.

Walker, C. (2005). Psychodermatology in context. In C. Walker, L. Papadopoulos (Eds.), Psychodermatology: The Psychological Impact of Skin Disorders (pp. 131-144). Cambridge University Press. 
Watson, D., Clark, L. A., Tellegen, A. (1988). Development and validation of brief measures of positive and negative affect: the PANAS scales. Journal of Personality and Social Psychology, 54(6), 1063-1070.

Willemsen, R., Haentjens, P., Roseeuw, D., Vanderlinden, J. (2011). Hypnosis and alopeciaareata: Long-term beneficial effects on psychological well-being. Acta DermatoVenereologica, 91(1), 35-39.

Wittbecker, L. M., von Spreckelsen, R., Bandholz, T. C., Lehmhaus, F. W., Schwarz, T., Gläser, R. (2021). From the (skin) doctor's office to the lecture hall: An innovative, practiceoriented, media-supported teaching project with supra-regional interdisciplinary usage options. Journal der Deutschen Dermatologischen Gesellschaft, 19(5), 694-705.

Zhang, X. J., Xu, H., Wang, A. P. (2021). Development and Evaluation of the Psychosocial Adaptation Questionnaire among Patients with Chronic Skin Disease. Dermatology, 237(4), 641-648. 10.1159/000514306 